METEOROLOGICAL NOTES.

MR. If. Allen has contributed an article to the American Meteorological Fournal for October, on the behaviour of pressure and temperature in low and high pressure system;. Recen investigations by $M$. Dechevrens (and others) tend to show that, while a high temperature accompanies a low pressure at sealevel, the fluctuations are reversed at some height above sea level. Mr. Allen maintains that this conclusion is not su, sported by his examination of observations made on Mount Washington, where the minimum pressure does not coincide with the passage of the storm centre over the station, but lars about eleven hours behind it, and he considers that this fact explains the peculiar results obtained by $M$. Dechevrens. The same number also contains an article by Prof. F. Waldo, "On the Absolute Reduction of Wind Observations at Sea." He recommends the use of some instrument to assist the judgment of different observers, at the actual time of observation.

THE results of meteorological observations made at the Radcliffe Observatory, Oxford, in the year I894, contain daily means of eye observations and of the self-recording instruments, com parisons of the mean monthly temperatures at 5 and ro5 feet above the ground, and rainfall observations on the ground at 22 and II 2 feet. Interesting tables are given showing the rela tions of pressure, temperature, \&c., under different winds. The total sunshine during 1884 was $1260^{\circ} 9$ hours, being 173.7 hours less than the mean of five years. The observations are reskoned for astronomical and for Greenwich mean time.

ON September 19, I887, the Russian Governnent gave notice that storm signals (consisting of day and night signals) would be made at their principal ports in the Black Sea. The signals are shown for forty-eight hours, unless instructions are received to Jower them before that time has elapsed : also, the cause assigned for hoisting each signal will be posted up at the respective signal stations. The day signals consist of a cone, hoisted either alone, or with a drum, both painted black, and each about 3 feet in diameter. The night signals consist of three red lights, hoisted at the angles of an equilateral triangle, of the same size as the cone used by day. These sirnals co:respond to those in this country-except that the drum is not now used, and night signals are only exhibited at very few stations.

In La Nature of November 12 M. Jules Girard contributes an article entitled "The Probable Temperature of the Pole," based upon the results of the circumpolar expeditions of $18 \mathrm{Sz}_{2}-83$, and upon the observations of some earlier expeditions, in which he has tabulated the mean temperatures for each month. From these data the author traces two principal centres of intense cold, one in the north of Siberia near the mouths of the Lena, and the other to the north of Hudson's Bay, near Boothia. The lowest mean temperature quoted for July is $30^{\circ}$ at. Jeannette Island, to the north of the islands of New Siberia, and the lowest mean for January is $-49^{\circ}$ at Fort Yukon, Alaska.

\section{THE BRITISH ASSOCIATION AND LOCAL} SOCIETIES.

THE third Annual Conference of Delegates of Corresponding Societies was held at Manchester, thirty-two of these affiliated Societies having nominated Delegates to attend the meeting. The following Report of the Conference, signed by Mr. Francis Galton as Chairman, and by Prof. R. Meldola as Secretary, has just been issued :-

At the first meeting of the Conference the chair was taken by Prof. W. Boyd Dawkins, F.R.S., the Corresponding Societies Committee being repre ented by Dr. J. G. Garson and Prof. R. Meldola, F.R.S., Secretary.

The Chairman, in opening the proceedings, stated that the British Association was anxious to be brought into as close a relationship as possible with the local Societies of this country. The work carried on by many of these Societies was of the greatest value to science, and it was felt that their efforts might be promoted by simplifying and unifying their labours. The present meeting was called for this purpose, and for that of bringing together the representatives of the various Corresp onding Societies.

The Secretary read the Report of the Corresponding Sucieties Committee which had been presented to the General Committee of the Association at the meeting on Wednesday, August 3I.
The names of the Delegates who desired to be attached to the Sectional Committees as "Delegate Members" were collected by the Secretary in accordance with the resolution passed at the Conference last year at Birmingham (see last Report, NATURE, vol. $x \times x v . ~ p .78$ ).

The Chairman called upon the Delegates to make any statements respectirg the action that had been taken by their Societies with reference to the suggestions put forward last year, and which had been embodied in the Report just read.

Prehistoric Remains Committee.-Mr. J. W. Davis stated that the Prehistoric Re nains Committee had been carrying on their work during the past year, and they proposed to apply for reappointment. Two reports had already been obtained relating to the bronze implements of the East and West Ridings of Yorkshire, and several others ha 1 been promised for next year.

Preservation of Stonehenge. - With reference to the preservation of Stonehenze, Dr. Garson stated that the resolution which had been submitted last year to the Deleģates at the Birmingham Conference had been considered by the Committee of Section $\mathrm{H}$, and, having been adopted by them, had been brought before the General Committee, and also accepted. He believed that in consequence of this action negotiations were now going on between the Council of the British Association and the proprietor of these remains. ${ }^{3}$

Prof. Boyd Dawkins remarked that the state of neglect into which Stonehenge had been allowed to fall had by no means been overstated in the resolution referred to. A person had recently been seen on a ladder chipping off piece. from the horizontal stone of one of the trilithons.

Ancient Monuments Act.-The Chairman and Dr. Garson made some remarks in explanation of the working of the Ancient Monuments Act. It was pointed out by the latter that the local Societies could do go dd service by inducing the proprietors of prehistoric remains to communicate with General Pitt-Rivers, the Inspector of Ancient Monuments, with the object of placing these remains under Government protection. The Chairman urged those Delegates who rep-esented the Northern, and especially the Scotch Societies to use their influence in inducing the owners of ancient remains to assist in carrying out the objects of the Act. In reply to a question by Mr. F. T. Mott, as to wheiher camps and earthworks were to be taken into consideration, the Chairman did not thiuk that any Government could be expected to become a landowner to the extent of all the earthworks in the country.

Provincia! Museums Committee. - With reference to the work of this Committee, Mr. F. 'T. Mott stated that they had been engaged duri.ıg the past year in collecting particulars respecting museums other than those in London. Considerable assistance had been given by the Secretaries of many of the local Societies. If the Committee was reappointed, as he hoped it would be, he thought there were one or two matters on which the local Sozieties might possibly render still more valuable aid. The Repo $t$ of the Committee was not yet passed, but it would, no doubt, be read in the course of the present meeting of the Association, and would then be accessible.

Prof. Boyd Dawkins stated that the schedule issued by this Committee was a very difficult one to fill up, and he expressed a hope that something shorter and simpler would be sent out.

The Rev. H. Winwood expressed similar views.

Mr. Robert Pullar and Mr. J. W. Davis mentioned two museums which the Committee had not heard of-viz. that of the Perthshire Society of Natural Science at Perth, and Mr. Davis's muscum at Chevinedge, Halifax.

Earth Tremors. - Prof. Lebsur stated that the subject of earth tremors, which he had brought forward at the Conference of Delegates last year at Birmingham, had since taken a more

1 The following extract relating to this matter is from the Council Report for I $886-87$, presented at the Manchester mee:ing :-

"That the Council be requested to consider the advisability of calling the a!tention of the proprietor of Ston zhenge to the danger in which several of th 3 stones are at the preient time from the birrow.ng of rabbits, and also to the desirability of removing the woodein prop; which support the horizontal stone of one of the trilithons; and in view of the great value of Stonehenge as an ancient national in inument, to exoress the hope of the Association that so ne steps will be taken to remedy these sources of danger to the stones."

The Council have carefully considere the question, and, having had the advantage of perusing the de:ailed repori recently prepared by a deputation of the Wilts Archæolozical and Natural History Society on the condition of the whole of the stones contituting Stozehe Society on the condition of the whole of the stones constituting Stonehenge, are of opinion that the proprietor should be ap?roached with the expression of a hope damage. 
practical shape, and that it now seemed to be time that a Committee of the British Association should be formed for taking the investigation in hand. Through the advocicy of Mr. Symons, who was unable to be present at the Conference, Sections A and $\mathrm{G}$ had that morning agreed to recommend the appointment of such a Committee in conjunction with Section C, which Section would be approached next day. The work to be done was of a preliminary character, and its object was rather to inquire into the best methods of conducting observations on earth tremors than to actually cause such observations to be made. The North of England Institute of Mining and Mechanical Engineers had since the Birmingham meeting, carried on a series of seismoscopic observations at Marsden in the county of Durham; and the daily results, extending over several months and compared with a barometric curve, were shown to the meeting in the form of a diagram by Mr. Walton Brown, the Secretary of the Newcastle Institute Committee. The Institute possessed also a more elaborate instrument, made after a pattern supplied by Prof. Ewing, which registered the intensity and direction of the tremors. Prof. Lebour stated that, although such instruments as the last mentioned were probably too costly to be placed at all desirable stations, this would not be the case with the simpler seismoscope, which recorded merely the fact of earth tremors having taken place and the time of their occurrence. Such records would be valuable, though limited. The Corresponding Societies, if they would interest themselves in the matter, might be the means of establishing a great network of seismoscopes with a few seismographs in suitable localities, and results of value would by this means be in all probability obtained. These results would be valuable altogether in proportion as wellequipped seismometrical observing stations were numerous. The expense must in any case be considerab'e in the aggregate, but need not be great in individual cases. A sufficiently good seismoscope might be had for about $£ 2$, a seismograph for $£$ I 4 to $£ 15$, and the cost of keeping them in order would not be great. Prof. Lebour hoped the Delegates present would help in establishing such a network of observing stations all over the country, and he stated, in concluding, that he would be happy to communicate with anyome interested in the subject.

Prof. Ewing, in response to the Chairman, said that from his experience of earth-tremor observations in Japan he could concur in the remarks of Prof. Lebour. To investigate fully the character of the motion, even at one station, required delicate and costly apparatus, and the cost was greatly increased when it was attempted to bring a number of stations into correspondence so as to determine the motion over a large area. It was possible, however, to record the fact that a tremor had occurred, and even to learn something of its character by means of inexpensive seismoscopes; and it certainly seemed to him that no bodie; could more appropriately undertake that work than the local Societies represented at the Conference acting in conjunction with a Committee of the Association. From recent observations it appeared probable that tremors would be found wherever they were tested for with sufficient delicacy, so that a Society undertaking the search was not likely to be disappointed.

At the second Conference the chair was taken by Prof. Boyd Dawkins, F.R S., who was succeeded by Mr. W. Topley, the Corresponding Societies Committee being further represented by Mr. G. J. Symons, F.R.S., Dr. Garson, Mr. William White, and Prof. R. Meldola, F.R.S., as Secretary.

The Chairman invited discussion on the recommendations received from the various Sections.

\section{SECTION A.}

Temperature Variation in Lakes, Rivers, and EstuariesThe following resolution was forwarded to the Secretary of the Conference by the Secretary of this Section:-

"That Mr. John Murray, Prof. Chrystal, Dr. A. Buchan, Rev. C. J. Steward, Hon. R. Abercromby, Mr. J. Y. Buchanan, Mr. David Cunningham, Mr. Isaac Roberts, Dr. H. R. Mill, and Prof. Fitzgerald be appointed a Committee to arrange for an investigation of the seasonal variations of temperature in lakes, rivers, and estuaries in various parts of the United Kingdom in co-operation with the local Societies represented at the Association ; and that Mr. John Murray be Secretary."

Dr. H. R. Mill, as representing this Committee, stated that the question proposed had not been fully worked out, but that the few observations made showed relations of a very interesting kind. As a branch of meteorology, this research was particularly promising, and was one in which the co-operation of local Societies would be valuable. He proposed that the Societies situated in the neighbourhood of rivers and estuaries which were willing to undertake this work should appoint some member to observe the temperature daily or weekly, as the case might be, in accordance with the rules to be drawn up by the Committee. It was first pr.sposed to ascertain how many observers would offer themselves in various parts of the country, then to draw up a scheme of observations and arrange for this being adopted.

Mr. G. J. Symons pointed out the necessity in such observations for having a well-considered scheme drawn up, as well as for having absolutely reliable thermometers, without which no observations would be of value. He also asked whether it was proposed that the cost of the instruments should be met by a grant from the British Association, or whether the Societies taking part in the observations should provide their own thermometers.

Mr. De Rance remarked that in the case of the Committee which had been formed for the observation of underground temperatures, and of which Prof. Leb our was a member, the thermometers had been supplied by the Association.

Mr. J. W. Davis raised the question as to whether it would be of use to extend the observations to the streams in manufacturing districts. $\mathrm{He}$ also asket what the Committee proposed to consider as an estuary.

The Rev. H. Winwood remarked that it would be necessary in all cases to record the depth at which the thermometer reading was taken. As a point of interest bearing upon the proposed observations, he stated that it had been observed that the temperature of the lakes in the Hebrides had been unusually high this year.

Prof. Lebour stated that the thermometers used by the Underground Temperature Committee had been supplied by the Association, but these instruments were very costly, and only a few observers had taken part in the work. He was of opinion that, if numerous Societies took part in the observations, these should in each case bear the expense.

D. Garson expressed a hope that the temperatures would be recorded on the Centigrade scale.

Dr. Mill, in reply, said that he understood that the fact of the investigation being sanctioned by a Committee of Section $A$ was a sufficient guarantee that it should be carried out in a thoroughly scientific manner with properly verified instruments of a uniform pattern, and employed in the same way. The experience of the Scottish Marine Station for three years suggested many precautions which should be adopted in this work. The temperature of streams in manufacturing districts should certainly be ascertained in as many cases as possible, in order to find whether the increase of temperature of a river passing through a manufacturing town is in any sense permanent. The term "estuary" should in his opinion be used as meaning all parts of a tidal river between the upper limit of the tide and the open sea. Each local Society should be asked to supply its own thermometers, but all these should be verified at Kew, or compared by some person appointed by the Committee. The observation would, of course, be made on a uniform plan, and it would, probably, be found more convenient to use the Fahrenheit scale, but the readings could be easily converted, if necessary.

\section{Section C.}

Mr. C. E. De Rance, who represented this Section, referred to the work of the three Committees which he had brought under the $\mathrm{n}$ itice of the Delegates on former occasions, viz. : (1) The Underground Waters Committee; (2) The Erratic Blocks Committee; and (3) The Sea Coasts Erosion Committee. (See last Report.)

The first of these Committees requires information as to the depth of wells, the sections passed through, the height at which the water stands before and after pumping, daily records of the height and chemical analyses of the waters.

The Erratic Blocks Committee wants information as to the position, size, and character of boulders of foreign origin that

s The constitution of these Committees remains as last year. The Secretaries are :-

Underground Waters, C. E. De Rance, 28 Jermyn Street, London, S.W Erratic Blocks, Rev. H. W. Crosskey, ${ }_{1} 7 \mathrm{G}$ Gugh Road, Edgbaston, Birmingham.

Sea Coasts Erosion, Wm. Topley, 28 Jermyn Street, London, S.W. The schedules and all other information will be fu nished on applicati in at the above addresses 
may occur in drift-covered areas, and are anxious that the position of the same should be noted on the I-inch map of the Ordnance Survey.

The Sea Coasts Erasion Connittee, like the other two Committees, has a circular form of inquiry, which can be obtained on application to Mr. Topley.

With reference to the work of this last Committee, $\mathrm{Mr}$. Topley stated that but little assistance had as yet been received from the local Societies. The Natural History Society of the Isle of Man had undertaken to collect information; and all similar Societies in maritime counties might greatly assist the Committee by local observation as to present changes, and by researches as to past conditions of the coast.

With respect to the work of the Erratic Blocks Committee, Prof. Meldola said that he had been authorized to state, on behalf of the Manchester Geological Society, that several members of that Society had been interesting themselves in the distribution of boulders in their district, and it was expected that their results would be available by the next meeting of the Association. It was also mentioned that Mr. Adamson had been rendering assistance to this Committee on behalf of the Yorkshire Naturalists' Union.

Mr. Ralph Richardson, as the representative of the Edinburgh Geological Society, pointed out that Scotland had been omitted from the localities dealt with by the Erratic Blocks Committee. He stated that much work in this field had alreacly been carried out under the auspices of the Royal Society of Edinburgh, and he hoped the Committee would be able to utilize their results.

Earth Tremors Committee.-Prof. Lebour stated that since the last meeting of the Conference the formation of a Joint Committee by Sections $\mathrm{A}, \mathrm{C}$, and $\mathrm{G}$ has been agreed to, and the resolution forwarded to the Committee of Recommendations. The resolution was the following :-

"That Sir F. J. Bramwell, Mr. E. A. Cowper, Mr. G. J. Symons, Prof. G. H. Darwin, Prof. Ewing, Mr. Isaac Roberts, Mr. Thomas Gray, Dr. John Evans, Prof. Lebour, Prof. Prestwich, Prof. Hull, Prof. Meldola, and Prof. Judd be a Committee for the purpose of considering the advisability and possibility of establishing in other parts of the country observations upon the prevalence of earth tremors, similar to those now being made in Durham in connection with coal-mine explosions, and that Prof. G. A. Lebour be the Secretary."

Mr. Symons and Mr. Topley made some remarks on the work of this Committee.

Mr. De Rance remarked that the proposed observations might possibly under certain circumstances become connected with the work of the Underground Waters Committee. Thus the Essex earthquake of April 22, I884, had caused a rise in the level of the water in Messrs. Courtauld's well at Bocking, which had reached its maximum in June of the same year. Since then the level had been gradually falling, and at its present rate it might be expected that the water would be at the same level as it was before the earthquake about next August.

\section{SeCtion D.}

Life-Histories of Plants. - Prof. Meldola said that during a recent visit to Oxford he had had an opportunity of hearing a suggestion in the course of a conversation with Prof. Bayley Balfour, which had appeared to him as likely to be of use to the members of local Societies. He had therefore invited Prof. Balfour to attend the Conference and explain his views on the suggested subject, but as that gentleman was prevented from being present he had forwarded the following communication :-

"It appears to me that much good scientific work might be done by members of local Societies in a direction which has not attracted so much attention in Great Britain as it deserves. The discovery and description of new forms, and the distribution of our indigenous plants, are in botany the lines upon which most of the energies of local Societies are principally spent, whilst habit, construction, and generally the features of life-history of plants come in for attention in quite a secondary way. This arises, I think, in great part from the prevalent notion that the facts of the life-history of our common plants are all well known, and that there is little, if anything, more to find out about them. That this is an erroneous idea may easily be shown-witness, for example, the interesting observations recently published by Sir John Lubbock-and there is a field for a great deal of sound work upon plants growing at our doors.

"Within recent years Mr. Darwin's work, followed up by that of such men as Hermann Müller, Kerner, Ogle, and others, has given a stimulus to observations of adaptations between the vegetable and animal kingdoms in connection with pollination in flowers; and many interesting facts about British plants have been brought to light by workers in local Societies. Bnt little has been done for the subject of the vegetative organs of these plants-I mean the arrangement, true nature, and structure of the members that carry on plant-life. In Germany, many years ago, Wydler and Irmisch published a splendid series of contributions to the knowledge of these features in indigenous German plants-why has this not been done for Britain?

"Now, I venture to think that good results would follow if you would bring before the Delegates at the meeting to-day the importance of encouraging the members of their Societies to study the life-histories of indigenous plants in their entirety, i.e. from the stage of embryo in the seed up to the production of fruit and seed again. Anyone who will take up this line of study will assuredly derive great pleasure from it, and will be able to add a great deal to the sum of our knowledge of plant-life. Such work can be well combined with the more usual systematic work; it can be easily accomplished, and it will be found to give much additional interest to the study of British botany."

Mr. C. P. Hobkirk considered that Prof. Balfour's letter was a very important one, and that, as therein suggested, the time and energies of the members of local Societies would be far more usefully employed by following the lines indicated by Prof. Balfour than, as at present, in simply collecting, naming, and registering local plants. As far as he was concerned, he was prepared personally, and also on behalf of the Yorkshire Naturalists' Union, which he represented, to do everything in his power to assist in carrying out practically Prof. Balfour's most useful proposition. Although the compilation of local floras was most useful and necessary work, yet the actual life-history of individual forms was now of really paramount importance, and members of local Societies should be urgently requested to carry on this work without delay.

\section{SECTION H.}

Ancient Monuments Act. - The Secretary read the following communication from General Pitt-Rivers :-

"I am much afraid I shall not be able to be present at the meeting of Delegates of local Societies on Tuesday; but the subject is so important for the preservation of these monuments that in case I an not there I write in order that you may know what my view of the matter is.

"Perhaps $I$ cannot do better than state in a few words what the work of the Inspector of Ancient Monuments is, and you will then see what kind of progress is likely to be made without some assistance such as has been proposed, ${ }^{1}$ and in what way the assistance of local Societies can be given.

"You are probably aware that in the original Act of 1882 fifty ancient monuments in Great Britain were scheduled as monuments to which the Act could apply at once if the owners were willing. Some persons suppose that by scheduling these monuments they were actually placed under the Act, but this is not the case. The scheduling was done without the knowledge or consent of the owners, and their consent had to be obtained both for these and for every other monument that has been since added to the list. This has entailed the examination and survey of all these monuments which are distributed over England, Scot'and, and Wales. The addresses of the owners had to be obtained, and this could only be done on the spot. After that the owners had to be visited personally, for I soon found an official letter, without a verbal explanation, almost invariably produced a refusal. On this account I have of late found it advisable never to approach an owner without a personal introduction, or without doing it in such a way as to induce him to consider the matter favourably. This mode of procedure for the whole country has, of course, taken a long time, and the result has been that abou half of these fifty monuments have been voluntarily put under the Act by their owners, and of the remainder some of the proprietors have refused, whilst in the case of others it has been found impracticable owing to peculiarities in the ownership. Al the monuments have, however, been carefully surveyed, planned, and drawn, and in every case in which there has been a refusal the owners have stated their intention of taking good care of the

I This refers to the work of the Prehistoric Remains Committee of the British Association. 
monuments themselves. In one case only a camp has been partly damaged, and this owing to mining operations invelving a question of a large sum of money which made it impossible for the Government to interfere. Other non-scheduled monuments have since been added to the list, and the number is steadily but not rapidly increasing.

"The Government makes no allowance for an assistant; not even so much as a man to holl the end of the tape in measuring, without which no proper survey of the monuments can be made, and I have to employ a private assistant, whom I take about with me at my oivn cost. With his assistance, and by dividing the work with him-I making the necessary notes and measurements while he is drawing-each monument takes on an average about one day; without an assistant the time would be about doubled. After this the owner has to be visited, and as he generally lives at a distance from the monument, this frequently takes another day or more. A great deal of this time might be saved by the assistance of persons living in the localities and with better chance of success.

"I issued a circular to a number of local Societies inviting them to co-operate, but few responded. One instance, however, shows what may be done in this way. Sir Herbert Maxwell has not only sent me the addresses of several owners in Wigtonshire and Kirkculbrightshire, but, by using his infuence with these, has been the means of placing several monuments under the Act. I would suggest that the same course might well be followed by others.

"The recommendation I would make is this:--Local Societies should (I) report to me what monuments in their district they think worthy of being put under the Act; (2) they should send me the names and addresses of the owners; (3) they should communicate with the owners, and, if possible, obtain their consent to have the monuments placed under the Act, subject, of course, to their subsequent acceptance by the Office of Works; and (4) they should report to me any damage that they find being done or contemplated either to the monuments under the Act, or to others not so protected. With such assistance I think that much more rapid progress may be made."

Prehistoric Remains Committee.-Mr. J, W. Davis stated that this Committee had been recommended for reappointment by the Committee of Section $H$. The recommendation is as follows :-

"That Sir John Lubbock, Dr. John Evans, Prof. Boyd Dawkins, Dr. R. Munro, Mr. Pengelly, Dr. Hicks, Mr. J. W. Davis, Prof. Meldola, and Dr. Muirhead be reappointed a Committee for the purpose of ascertaining and recording the localities in the British Islands in which evidences of the existence of prehistoric inhabitants of the country are found; and that Mr. J. W. Davis be the Secretary."

Prof. Lehour suggested that it would be convenient if, in registering prehistoric remains, the Committee would adopt a uniform scheme of signs-if possible, an international one.

Mr. William Gray stated that the work of registering ancient remains had been carried on for twenty-five or thirty years by members of their Society (Belfast Naturali: ts' Field Club) and others in Ircland, and they had long felt the want of some central organization such as that of the present Committee. He also alluded to the necessity for a uniform system of signs.

Mr. William White remarked upon the difficulty which private individuals often experienced in approaching the proprietors of ancient remains, and pointed out that individual efforts would be likely to be more successful if members of local Societies could make overtures backed up by the sanction of a British Association Committee such as the present one.

Work of the Corresponding Societies Committee. -The Secretary stated that during the present meeting of the Association an important resolution had been framed at the instigation of Sir Douglas Galton, with the object of extending the powers of their Committee. According to the present rules the Committee was nominated by the Council and appointed by the General Committee, but they had no power of submitting resolutions or recommendations to the Committee of Recommendations or to the General Committee. The present resolution, which was calculated to give them the necessary power, and thus to put them on the same footing as the Committees of the Sections, was as follows :-

"That the Conference of Delegates of Corresponding Societies be empowered to send recommendations to the Committee of Recommendations for their consideration, and for report to the General Committee."
The Secretary had succeeded that morning in getting this resolution passed by the Committees of Sections $B$ and $C$, and it had been forwarded by them in due form to the Committee of Recommendations, by whom it had also been accepted. It was subsequently submitted to the General Committee, and accepted by them on the understanding that the recommendations so forwarded should not clash with the recommendations sent up by the Sectional Committees.

The Secretary remarked that he would take the present opportunity of explaining away a misunderstanding that had arisen on the part of some of the local Societies. Some of these had nominated Delegates to attend the Manchester meeting without having previously submitted any claim for election as Corresponding Societies. Such Delegates could not be officially recognized by the Association, as it was only those Societies which had been admitted as Corresponding Societies, and which were still on the list, that were thus entitled to be officially represented. According to the Rules no Society can be admitted without first sending in a formal application, accompanied by a specimen of its publications; this application would be considered by the Corresponding Societies Committee, and only in the event of the Society being recommended for election by this Committee, and this recommendation confirmed by the General Committee, would it be admitted to the privileges of a Corresponding Society.

At the termination of the meeting a vote of thanks was passed to Prof. Meldola, on the motion of Prof. Lebour, for the services which he had renclered as Secretary to the Committee and to the Conferences.

\section{THE METEOROLOGY OF OXFORD.'}

THE forty-second volume of the Observations of the Radcliffe Observatory has recently been published, and is in nearly all respects a continuation of the previous publications. The Radcliffe takes precedence of all our British Observatories as regards the length of time over which the published hourly observations of atmospheric pressure and temperature extend; to which is to be added a commendable fullness, far from common, with which many other observations have been made and given to the public for a long term of years.

At Oxford, atmospheric pressure attains the maximum, $29^{\circ} 760$ inches, in June, and falls to the minimum, $29^{\circ} 677$ inches, in March, to which the mean of October, $29^{\circ} 680$ inches, closely approximates. The annual mean is $29^{\circ} 720$ inches; the highest during the previous thirty years being $29^{\circ} 785$ inches in 1858 , and the lowest $29^{\circ} 572$ inches in 1872 , the year to be long remembered for its excessive rainfall. Temperature rises to the maximum, $6 \mathrm{I}^{\circ} \cdot 7$, in July, and falls to the minimum, $38^{\circ} \cdot 8$, in January, the annual mean being $49^{\circ} 2$. The warmest year was I 868 , with a mean of $51^{\circ} 4$, and the coldest mean $45^{\circ} 5$ in 1879 . Of individual months, the warmest was July 1859 , the mean of which was $66^{\circ} \cdot 5$, while the mean for February 1855 was only $29^{\circ} \cdot 5$, giving thus a mean monthly range of $37^{\circ} \circ$. The rainfall reaches the maximum, $2.8 \mathrm{r}$ inches, in October, and falls to the minimum, I.62 inch, in March, and the mean annual amount is 26.42 inches. The extreme annual amounts were $40^{\circ} 42$ inches in $185^{2}$ and 17.56 inches in 1870 . The month of heaviest rainfall was October 1875 , when 7.53 inches fell, and the lightest fall was 0.18 inch in September I865, when temperature was unusually high for the season.

The diurnal curves of pressure approach closer than those of any other British Observatory of which we have records to the seasonal phases of these curves for continental situations. On the mean of the year, the first minimum occurs about $4 \mathrm{a} . \mathrm{m}$. and the maximum at 9 a.m.; and the second minimum at 3.30 p.m. and maximum at Io p.m., - the former being earlier in summer and later in winter, whereas the afternoon phases are the reverse of this. In June the time between the first and second maximum is $14 \frac{1}{2}$ hours, but in winter only 12 hours.

Of quite exceptional interest are some of the other diurnal phenomena at Oxford, notably the diurnal distribution of thunderstorms, sheet lightning, and auroras. We have compiled the following table showing the sums of the times of occurrence

I "Results of Meteorological Observations made at the Radcliffe Observatory, Oxford, in the Year $188_{4}$, under the Superintencence of E. J. S tone, F.R.S." (Oxford, r887.) 